\title{
Canopy Area and Aboveground Mass of Individual Redberry Juniper (Juniperus pinchotii) Trees
}

\author{
R. J. Ansley, ${ }^{1}$ M. Mirik, ${ }^{2}$ B.W. Surber, ${ }^{3}$ and S. C. Park ${ }^{4}$ \\ Authors are ${ }^{1}$ Professor, ${ }^{2}$ Associate Research Scientist, ${ }^{3}$ Research Technician, and ${ }^{4}$ Assistant Professor, Texas AgriLife Research, Vernon, TX 76385, USA.
}

\begin{abstract}
There is increasing interest in using canopy area to quantify biomass of invasive woody plants on large land areas of rangelands for a variety of reasons. For those woody species that emphasize lateral canopy growth over vertical growth it may be possible to relate canopy area to aboveground mass (AGM). Our objective was to determine the utility of external canopy measurements (area, volume, and height) for predicting AGM and the percentage of AGM that is wood (PW; i.e., stems $>3$ cm diameter) in individual redberry juniper (Juniperus pinchotii Sudw.) plants in west Texas. The canopy area to height relationship was curvilinear and indicated that at heights $>3 \mathrm{~m}$, there was more lateral (canopy area) than vertical canopy growth. We found a strong linear relationship between canopy area and AGM $\left(r^{2}=0.94\right.$; AGM range $9 \mathrm{~kg}$ to $\left.688 \mathrm{~kg}\right)$ and it appeared that AGM could be predicted in individual trees from canopy area. Moreover, the canopy area/AGM relationship developed from smaller trees was able to adequately predict AGM of larger trees. Height was a less effective predictor of AGM $\left(r^{2}=0.66\right)$, and incorporation of height with canopy area to determine canopy volume did little to improve accuracy of estimating AGM over canopy area alone. The canopy area/PW relationship was curvilinear (the rate of increase in PW declined in larger trees) and PW reached 60-70\% in the largest trees.
\end{abstract}

\section{Resumen}

Aumenta el interés por usar el área del dosel para cuantificar la biomasa de plantas leñosas invasoras en grandes extensiones de pastizales por diversas razones. Para esas especies leñosas que resaltan el crecimiento lateral del dosel lateral sobre el crecimiento vertical puede ser posible relacionar el área de dosel con la biomasa aérea (BA). Nuestro objetivo fue determinar la utilidad de medir el dosel externo (área, volumen y altura) para predecir BA y el porcentaje de BA que es madera (PW, ejemplo tallos $>3 \mathrm{~cm}$ de diámetro) en plantas individuales de junípero rojo (Juniperus pinchotii Sudw.) en el oeste de Texas. El área del dosel con la relación de altura fue curvilínea e indicaba que la altura $>3 \mathrm{~m}$ fue más lateral (área del dosel) que el crecimiento vertical del dosel. Encontramos una fuerte relación linear entre el área del dosel y BA $\left(r^{2}=0.94\right.$; BA rango $9 \mathrm{~kg}$ a $\left.688 \mathrm{~kg}\right)$ y esto parece que BA puede ser predicha en arboles individuales de área del dosel. Sin embargo, la relación área del dosel/BA desarrollada de arboles pequeños fue posible predecir adecuadamente BA de arboles grandes. Altura del árbol fue un factor de predicción menos efectivo de BA $\left(r^{2}=0.66\right)$, al incorporar altura con área del dosel para determinar el volumen del dosel mejoro muy poco la exactitud la estimación de BA sobre el área del dosel por sí solo. La relación de área del dosel/madera(PW) fue curvilínea (la tasa de incremento de madera(PW) declino en arboles grandes) y la madera (PW) alcanzo 60-70\% en arboles grandes.

Key Words: allometry, bioenergy, brush management, carbon stocks, remote sensing, woody plant encroachment

\section{INTRODUCTION}

Nondestructive measurements of plant attributes (e.g., height, canopy dimensions, stem diameter) have long been used to estimate mass, area, or volume of plants. However, with respect to semiarid rangeland shrubs, previous studies have emphasized estimation of leaf area or leaf and new shoot mass, and not total aboveground mass (AGM; Mason and Hutchings 1967; Miller et al. 1987). Reasons for this relate to the research focus being on quantifying annual production (Peek 1970), estimating leaf gas exchange (Owens and Schreiber 1992; Ansley et al. 1998; Hicks and Dugas 1998), or determining wildlife browse availability (Bryant and Kothmann 1979; Hughes et al. 1987).

This research was funded in part by a grant from John Deere Renewables, Inc., and the Texas Agrilife Bioenergy Initiative Fund.

Correspondence: R. James Ansley, Texas AgriLife Research, PO Box 1658, 11708 Hwy 70 S, Vernon, TX 76385, USA. Email: jansley@ag.tamu.edu

Manuscript received 28 June 2011; manuscript accepted 6 November 2011.
Recent interest in quantifying ecosystem carbon stocks and/or potential bioenergy uses on rangelands has increased the need for using nondestructive methods to estimate total AGM. Studies that have nondestructively estimated AGM have usually relied on measurements of stem diameters (or basal stem area), plant height, or canopy volume to predict AGM (Whisenant and Burzlaff 1978; Felker et al. 1983; Brand and Smith 1985; El Fadl et al. 1989; Tietema 1993; Thomson et al. 1998; Rosenschein et al. 1999; Jenkins et al. 2003; Williams et al. 2005; Hughes et al. 2006; Ansley et al. 2010; Alvarez et al. 2011). Fewer studies report canopy diameter or canopy area (i.e., crown area) to estimate AGM (Miller et al. 1981; Tietema 1993; Navar et al. 2004; Padron and Navarro 2004; Northup et al. 2005; Cleary et al. 2008; McGinnis et al. 2010). Many papers indicate that canopy area was measured but then report only stem diameter or canopy volume data as these provided the best regression fits for AGM prediction. However, if a reasonable relationship exists between canopy area and AGM, then there may be potential for estimating AGM from two-dimensional aerial images or highresolution satellite images (Asner et al. 2003; Booth et al. 2006; 
Masera et al. 2006; Massada et al. 2006; Strand et al. 2008; Huang et al. 2009; Davies et al. 2010; Starks et al. 2011).

Of the studies that have predicted rangeland woody plant AGM from canopy area, many have focused on small-sized shrubs and trees with few large individuals. However, many of the relationships between canopy area and AGM are power curves (Ludwig et al. 1975; Brand and Smith 1985; Navar et al. 2004), so the potential for error in estimating biomass of large individuals from equations developed with only small individuals within a species is high. Thus, there is a need for developing canopy area/AGM equations that include a sufficient number of individuals that represent the maximum size attainable within a region. This is especially critical for larger rangeland woody plants such as several species of Prosopis and Juniperus that may have sufficient AGM to be considered as bioenergy feedstock (Ansley et al. 2010; Starks et al. 2011).

Redberry juniper (Juniperus pinchotii Sudw.) occurs on more than 4.7 million ha of rangeland in the western half of Texas (SCS 1988). Originally, it was restricted to rocky slopes and hillsides but it has encroached into other rangeland sites in the last $120 \mathrm{yr}$ due to livestock overgrazing and reduced frequency and intensity of fires (Ansley et al. 1995; Ueckert et al. 2001). High densities of this and a closely related species in central Texas, Ashe juniper (Juniperus ashei Buchh.), can significantly reduce grass production and species diversity by competing for light, soil moisture, and soil nutrients, and can greatly increase the risk for soil erosion (McPherson and Wright 1990; Ansley et al. 2006).

Few studies have developed nondestructive measurements for estimating AGM of Juniperus species and these data are not available for redberry juniper (Miller et al. 1981; Grier et al. 1992; Jenkins et al. 2003; Sabin 2008; Starks et al. 2011). Measurement of basal stem diameter (or diameters) and/or diameter at breast height is difficult in redberry juniper because it has a very compact canopy with a high density of low growing stems that restricts access to central base stems. Thus, the use of outer canopy dimensions may be the best option for nondestructively estimating AGM in this species. Because this species often has a spherical growth form, canopy area, canopy volume, and height should all reliably predict AGM. Because of the dense foliage in this and other Juniperus species, it is much easier in the field to measure plant height than to measure canopy area. Canopy area typically requires at least two perpendicular measurements of canopy diameter, usually accomplished by inserting a measuring pole through the canopy. Thus, field measurement of plant height to estimate AGM would be useful.

Several studies have demonstrated that as rangeland trees and shrubs increase in size, the percentage of AGM that is wood increases and the percentage that is leaf and twig decreases (Cleary et al. 2008; Ansley et al. 2010). Because juniper is an evergreen that maintains a large amount of leaf and twig biomass relative to total plant AGM (Tiedemann and Klemmedson 2000), we were also interested in determining whether canopy measurements could predict the percentage of AGM that is wood (PW) in redberry juniper. Because the wood component would likely be the most desirable component for bioenergy uses, it is important to know the minimum canopy sizes that will yield sufficient woody material.

Our objective was to determine the utility of external canopy measurements (area, volume, and height) for predicting AGM

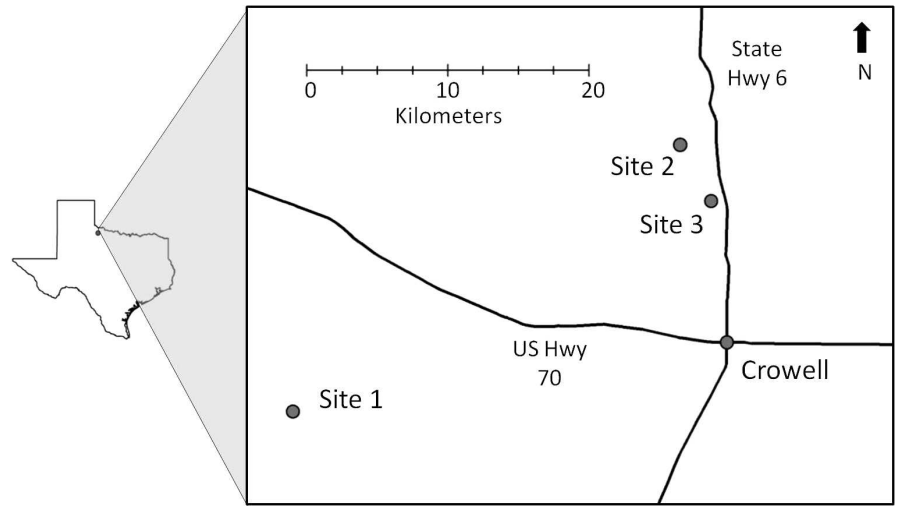

Figure 1. Map of the three redberry juniper harvest sites in northcentral Texas, north and west of Crowell, Texas.

and the PW (i.e., $>3 \mathrm{~cm}$ diameter) in individual redberry juniper plants. We also wished to determine the utility of using measurements gained from small plants to estimate biomass of large individuals. Our focus was on isolated trees and not those in clusters or groves whose canopy dimensions could be markedly affected by neighboring trees.

\section{METHODS}

\section{Study Sites}

Data were collected from three sites in Foard County, Texas, approximately $220 \mathrm{~km}$ southeast of Amarillo, Texas, that were within $32 \mathrm{~km}$ of each other: site 1 , lat $33^{\circ} 56^{\prime} \mathrm{N}$, long $100^{\circ} 00^{\prime} \mathrm{W}$, elev. $509 \mathrm{~m}$; site 2 , lat $34^{\circ} 6^{\prime} \mathrm{N}$, long $99^{\circ} 45^{\prime} \mathrm{W}$, elev. $443 \mathrm{~m}$; site 3 , lat $34^{\circ} 4^{\prime} \mathrm{N}$, long $99^{\circ} 44^{\prime} \mathrm{W}$, elev. $436 \mathrm{~m}$ (Fig. 1). Sites were selected to obtain a wide range of tree sizes. Mean annual rainfall at Crowell is $616 \mathrm{~mm}$ (NOAA 2006). The sites were dominated by redberry juniper and honey mesquite (Prosopis glandulosa Torr.) and the herbaceous understory was dominated by the perennial $\mathrm{C}_{4}$ shortgrass, buffalograss (Bouteloua dactyloides [Nutt.] J.T. Columbus). Other grasses were $\mathrm{C}_{4}$ perennial midgrasses tobosagrass (Pleuraphis mutica Buckl.), sideoats grama (Bouteloua curtipendula [Michx.] Torr.), and dropseeds (Sporobolus spp.), and the $\mathrm{C}_{3}$ perennial midgrass Texas wintergrass (Nassella leucotricha [Trin. and Rupr.] Pohl.; NRCS 2009). Soils at site 1 were fine, mixed, active, thermic Typic Haplustepts of the Vernon series and fine-silty, mixed, superactive, thermic Typic Calciustolls of the Quanah series; soils at site 2 comprised patches of the Vernon series and fine-loamy, mixed, active, thermic Typic Haplustalfs of the Cobb series; and soils at site 3 were a Vernon series/Badland complex (NRCS 2011). Slopes on all sites were $<2 \%$.

\section{Measurements}

Forty redberry juniper trees were selected for the study based on the criterion that at least $75 \%$ of the canopy perimeter of each tree was at least $1 \mathrm{~m}$ apart from the canopy perimeter of other trees. Initially, 80 trees met this standard and were grouped into seven canopy area classes (A: $1-10 \mathrm{~m}^{2}, \mathrm{~B}: 10-20 \mathrm{~m}^{2}$, C: 20 $30 \mathrm{~m}^{2}, \mathrm{D}: 30-40 \mathrm{~m}^{2}, \mathrm{E}: 40-50 \mathrm{~m}^{2}$, F: $50-60 \mathrm{~m}^{2}$, and G: $>60 \mathrm{~m}^{2}$ ) with 18-20 trees selected in each of the first two classes and six to eight trees in the other classes. Approximately 50\% of 
individuals in each size class were randomly selected for harvest and AGM measurement. Site 1 (17 trees harvested) had trees in size classes A and B; site 2 (10 trees) had trees size classes B, C, and D; and site 3 (13 trees) had trees in size classes E, F, and G.

All trees were measured and harvested during October 2010March 2011. Tree height (height), canopy diameter along two directions (longest axis and perpendicular to longest) and number of basal stems were measured on each tree prior to harvest. Canopy area was determined using the ellipse equation: $\pi \cdot a \cdot b$, where $a=$ radius of longest canopy axis and $b=$ radius of perpendicular canopy axis. Canopy volume was determined based on the ellipsoid equation: $4 / 3 \cdot \pi \cdot a \cdot b \cdot c$, where $a=$ radius of longest canopy axis, $b=$ radius of perpendicular canopy axis, and $\mathrm{c}=$ vertical radius (i.e., height/2; after Cleary et al. 2008).

Wood tissue ( $>3 \mathrm{~cm}$ stem diameter, including any bole wood) was separated from leaf and twig tissue (hereafter termed "leaf/ twig") in all trees (after Tiedemann and Klemmedson 2000). Total wet weight of both components for each tree was measured within $2 \mathrm{~h}$ after tree felling. Leaf/twig and wood subsamples were collected for each tree, weighed as wet weight, oven-dried at $60^{\circ} \mathrm{C}$ to a constant weight, and used to convert fresh mass of each fraction to oven-dry mass for each tree. PW was calculated for each tree.

\section{Statistical Analyses}

Data from the three sites were pooled to maximize the range of independent variable values for each regression analyses. Relationships between height, canopy area, canopy volume, AGM, and PW were analyzed using linear and curvilinear regressions (SigmaPlot Version 11, Jandel, CA). The DurbinWatson test was used to test residual independence. The Kolmogorov-Smirnov test was used to test for normality. Nonnormal distributions were multiplied by 10 and logtransformed to develop best fit linear models; however, all figures show nontransformed data to illustrate points of variation in the relationships. Significance was determined at $P \leq 0.05$. To further test capability of canopy area to predict AGM, trees from two sites were pooled and the canopy area vs. AGM regression from those sites was used to predict AGM of trees from the third site, based on canopy area measurements from the third site. This was done using all site combinations. In addition, for objective 2, we tested the ability of the regression developed for the smallest trees (site 1) to predict AGM of the largest trees (site 3). The canopy area/AGM regressions for all tests were performed with derived $Y$ intercepts and with the $Y$ intercept $=0$. Mean percentage of deviation, calculated using the formula: $\left(\sum\right.$ [actual AGM - predicted AGM/actual AGM] $\left.\cdot 100\right) / n$, was used as the test variable.

\section{RESULTS}

Means and ranges of the measured variables confirm that there was a broad range of values for each variable measured (Table 1). The upper ranges of canopy dimensions and AGM are some of the largest we have observed for redberry juniper. Dye et al. (1995) reported that the largest redberry junipers on three sites northwest of San Angelo, Texas averaged $3.4 \mathrm{~m}$ height and $3.9 \mathrm{~m}$ canopy diameter, which is about the median of our canopy size ranges and much smaller than our largest trees
Table 1. Mean, standard error $(n=40)$, and range of allometric variables and oven-dry masses and percentage of wood mass measured on individual redberry juniper plants, north Texas.

\begin{tabular}{lcl}
\hline \multicolumn{1}{c}{ Variable } & Mean \pm SE & \multicolumn{1}{c}{ Range } \\
\hline Canopy height $(\mathrm{m})$ & $4.0 \pm 0.2$ & $1.5-6.1$ \\
Canopy diameter $(\mathrm{m})$ & $5.4 \pm 0.4$ & $1.3-9.7$ \\
Canopy area $\left(\mathrm{m}^{2}\right)$ & $27.9 \pm 3.5$ & $1.4-73.9$ \\
Canopy volume $\left(\mathrm{m}^{3}\right)$ & $88.9 \pm 12.7$ & $1.4-256.2$ \\
Tree AGM $^{1}(\mathrm{~kg})$ & $232.2 \pm 30.5$ & $9.3-688.4$ \\
Percentage of wood mass & \\
$\quad$ total of & & \\
\hline
\end{tabular}

${ }^{1}$ AGM indicates aboveground biomass.

${ }^{2}$ Wood mass $=$ all wood that was $>3 \mathrm{~cm}$ diameter.

measured. The largest trees in our study were not as large as what we have observed (R. J. Ansley, unpublished data, 2010) for Ashe juniper in parts of central Texas.

All regression relationships passed tests for residual independence and normality except for height vs. AGM and height vs. PW. The relationship between canopy area and height was curvilinear; the rate of height increase declined with increasing canopy area (Fig. 2a). The relationship between canopy diameter and height showed an increasing deviation from the 1:1 line in favor of canopy diameter (i.e., toward oblate ellipsoid canopy shape) with increasing canopy size (Fig. 2b).

There was a strong linear relationship between canopy area and AGM (Fig. 3a) and between canopy volume and AGM (Fig. 3b). The nontransformed relationship between height and AGM was curvilinear (Fig. 3c). Height was a less effective predictor of AGM $\left(r^{2}=0.66\right)$. The log-transformed linear relationship between height and AGM increased the $r^{2}$ (Table 2).

Pooling two sites to predict AGM of the third site revealed that the canopy area/AGM regression from trees from sites 1 and 2 (size classes A-D) slightly underestimated (mean deviation: $-4.04 \%$ ) the AGM of the larger trees from site 3 (size classes E-F; Table 3). The regression derived from pooling sites 1 and 3 slightly overestimated AGM for site 2. The regression derived from pooling large trees from sites 2 and 3 overestimated (mean deviation $=24.7 \%$ ) the AGM of small trees from site 1 . Mean percentages of deviation were much lower for all comparisons $(<2.5 \%)$ when the $Y$ intercept was passed through zero.

The canopy area/AGM regression from trees from site 1 alone (size classes A-B) effectively predicted (mean deviation $=2.96 \%$ ) the AGM of the larger trees from site 3 (Table 3). However, unlike the other comparisons, the mean percentage of deviation increased when the $Y$ intercept was passed through zero.

The relationship between canopy area and PW was curvilinear (Fig. 4a). PW increased sharply as canopy area increased from $0 \mathrm{~m}^{2}$ to $10 \mathrm{~m}^{2}$, but the rate of increase in PW decreased with larger canopy areas. A similar relationship occurred between canopy volume and PW (Fig. 4b), with the exception that the rate of increase in PW at volumes $>30 \mathrm{~m}^{3}$ was lower than was found with canopy areas $>10 \mathrm{~m}^{2}$. The nontransformed relationship between height and PW was a log function with high variability in PW at heights between $4 \mathrm{~m}$ and $5.5 \mathrm{~m}$ (Fig. 4c). The log-transformed linear relationship between height and PW increased the $r^{2}$ (Table 2). 

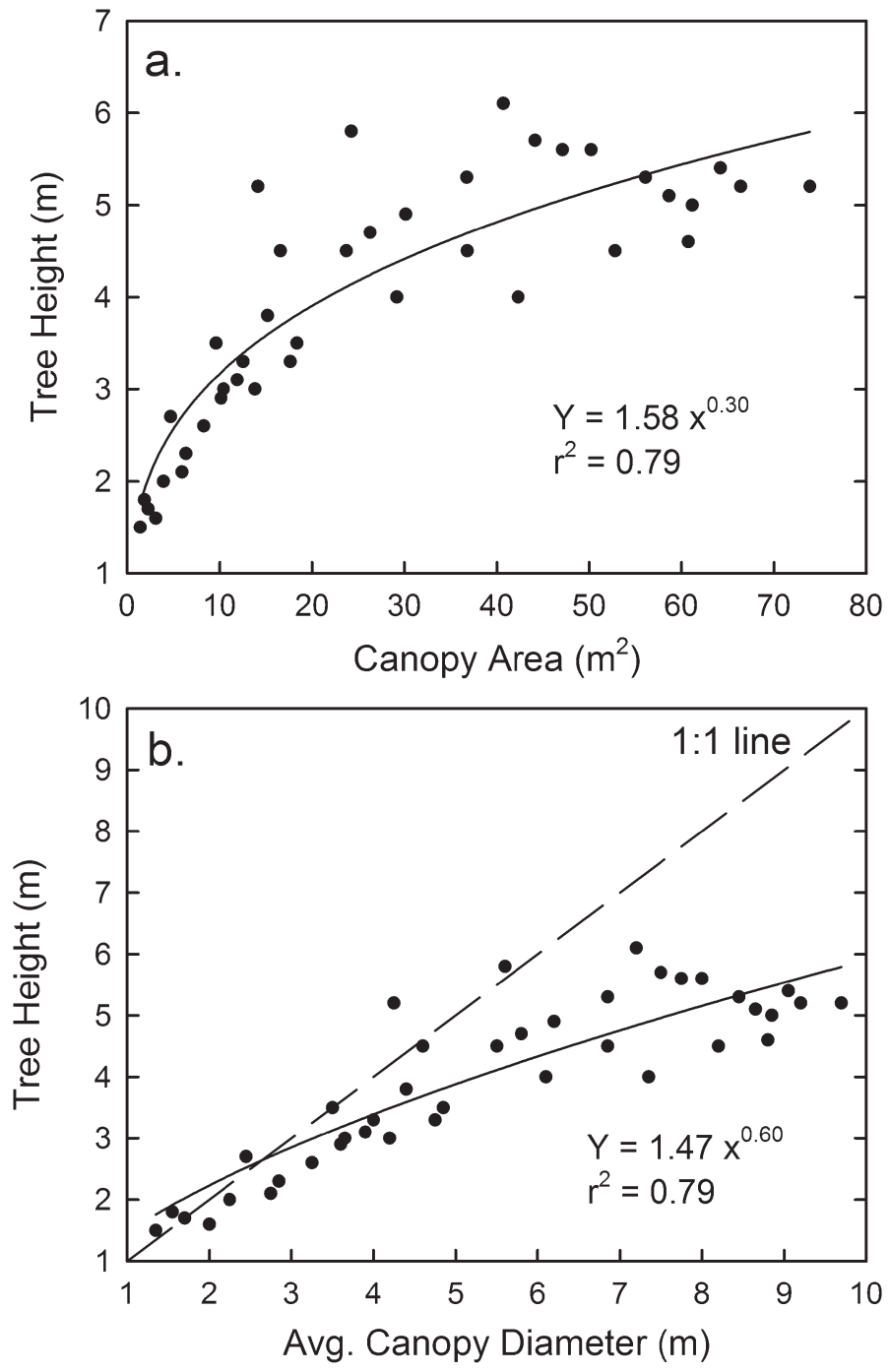

Figure 2. Relationship between a, tree height and canopy area, and b, average canopy diameter (mean of the two measurements per tree) and height compared to a 1:1 line of individual redberry juniper plants in north Texas.

\section{DISCUSSION}

Results suggest that canopy area can be used to predict AGM of individual, isolated redberry juniper trees. The nontransformed relationship was linear, which agrees with findings of Sabin (2008) who made similar measurements on western juniper in Oregon. The slope of our canopy area/AGM curve (8.58; Fig. 3a) was similar to the 9.72 found by Sabin (2008) over a similar range of juniper canopy sizes, but our $Y$ intercept was considerably lower $(-6.82 \mathrm{~kg}$ vs. $37.51 \mathrm{~kg})$. Thus, for a given canopy area, Sabin (2008) would have predicted a higher AGM than our data would have and this difference would have increased with increasing canopy area. Similarly, Miller et al. (1981) predicted greater AGM of Utah juniper (Juniperus osteosperma [Torr.] Little) in Nevada for a similar range of canopy areas (which we calculated from their canopy diameter data using $\pi \cdot r^{2}$ ) than did our predictions.

It is possible that redberry juniper does not attain as great a bole wood weight as do western juniper or Utah juniper for any
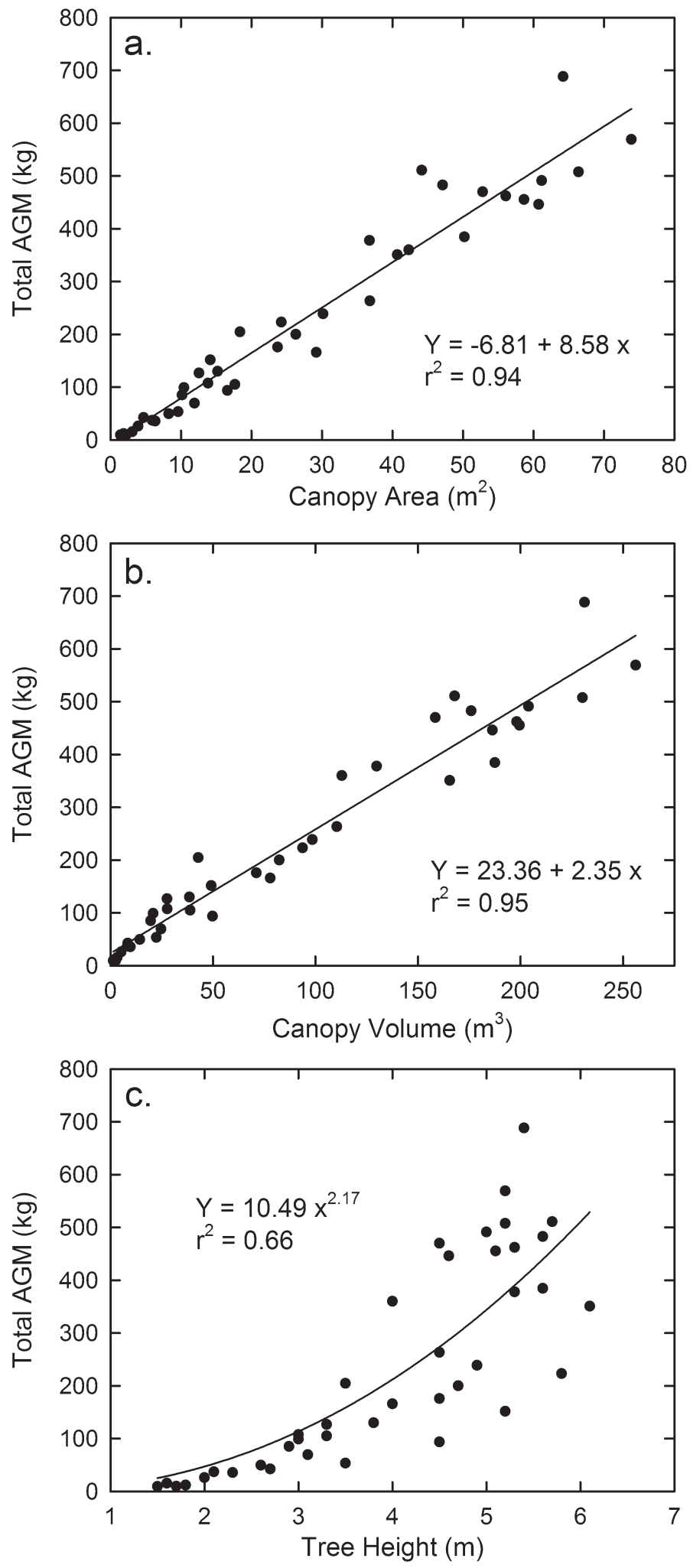

Figure 3. Relationship between a, canopy area and aboveground biomass (AGM), b, canopy volume and AGM, and c, tree height and AGM of individual redberry juniper plants in north Texas.

given canopy size and this could explain our lower AGM values. Canopy form of these isolated redberry juniper trees changed from spherical or slightly oblate ellipsoid (height $<$ diameter) to strongly oblate ellipsoid in larger trees. Young trees increased 
Table 2. Log-transformed linear regression analyses of relationships between $H T^{1}{ }^{1}$ total $A G M$, and $P W{ }^{2}$

\begin{tabular}{lcccccc}
\hline \multicolumn{1}{c}{ Equation } & $r^{2}$ & $S E E$ & $S E_{y 0}$ & $S E_{a}$ & D-W & K-S \\
\hline $\log (\mathrm{AGM})=2.86(\log H T)-1.33$ & 0.88 & 0.18 & 0.27 & 0.17 & 1.67 & $P=0.91$ \\
$\log (\mathrm{PW})=0.85(\log H \mathrm{HT})+1.30$ & 0.73 & 0.09 & 0.13 & 0.08 & 1.48 & $P=0.07$ \\
\hline
\end{tabular}

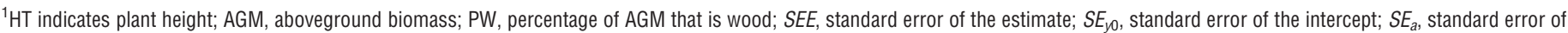
the slope; D-W, Durbin-Watson test for residual independence (pass if between 1.5 and 2.5); K-S, Kolmogorov-Smirnov test for normality (pass if $P>0.05$ ).

${ }^{2}$ Both regressions were significant at $P<0.0001$. Total $\mathrm{df}=40$, except $\mathrm{PW}=35$ (some $\mathrm{PW}$ values $=0$ and could not be log-transformed).

height and canopy area proportionally, but after trees reached $3 \mathrm{~m}$ height, the trees grew outward more than upward. This growth pattern suggests that larger trees may have allocated more mass toward smaller diameter wood to accommodate increases in lateral branching rather than increasing the heavier bole wood mass that would be needed to support a more vertically oriented growth.

In comparing trees from the three different sites, the data collected for smaller size classes A-B and A-D were able to successfully predict the AGM of larger trees from site 3 (sizes E-G). Larger trees were less effective for predicting AGM of smaller trees unless the $Y$ intercept was forced to pass through zero. Related to objective 2 , the results indicate that for this species a sampling of smaller trees may be sufficient for predicting AGM of larger trees.

The curvilinear relationship between height and AGM indicates that the reliability of predicting AGM from height alone is suspect, especially in trees taller than $3 \mathrm{~m}$. Canopy volume, which was calculated from canopy area and height, was only marginally better than canopy area at predicting AGM. We conclude that there was no advantage to measuring height in developing an adequate predictor for individual plant AGM because canopy area provided nearly as accurate an estimation of AGM as did canopy volume.

Our study indicates that PW can be estimated reasonably well with canopy area and volume measurements. However, our PW results are somewhat different than what Tiedemann and Klemmedson (2000) reported for western juniper in Oregon. Within a 3-6-m height range, redberry juniper PW was predicted to be $38-60 \%$ (Fig. 4c), which is higher than the $25-35 \%$ reported within three plant height classes (average $3.3 \mathrm{~m}, 4.8 \mathrm{~m}$, and $7.0 \mathrm{~m}$ height) of western juniper (Tiedemann and Klemmedson 2000). Thus, it does not appear that redberry juniper PW is the same as western juniper PW for any given canopy size. This again may relate to the more oblate ellipsoid growth form of redberry juniper.

The most accurate method of nondestructively measuring AGM in most rangeland trees and large-sized shrubs is to measure basal stem diameter (Tietema 1993; Northup et al. 2005). For example, Padron and Navarro (2004) found a better relationship between stem diameter and AGM than between canopy area and AGM in Prosopis pallida in Peru. Tietema (1993) found in three species of Acacia in Southern Africa that the relationship between basal stem area and AGM was stronger $\left(r^{2}=0.93-0.96\right)$ than the relationship between canopy area (i.e., crown area) and AGM $\left(r^{2}=0.76-0.89\right)$. Base stem diameter is not easily measured in redberry juniper because of the lateral canopy growth and many low-growing branches in larger trees. Thus, this measurement is not a viable alternative. However, basal stem measurements may not be necessary for nondestructively estimating AGM in this species because the canopy area/ AGM relationship was so strong. Further research on other sites is needed to confirm this.

\section{IMPLICATIONS}

Our study measured individual, isolated redberry juniper trees to establish fundamental relationships between canopy dimensions and AGM without the crowding effects from neighboring trees. The strong relationship exhibited between canopy area and AGM could be used for a variety of purposes, including estimation of biomass for bioenergy purposes or quantification of regional carbon stocks. In addition, our data suggest that for this species a sampling of smaller trees may be adequate to predict biomass of larger trees.

We note that our sampling and regressions were limited to isolated redberry juniper trees and these data may not apply to trees that grow in groves and clusters or to trees of other species. Canopy shapes of trees growing in clusters may be quite different than isolated trees, as canopy overlap in these settings could significantly alter estimates of AGM based on canopy area. To estimate biomass of such clusters from canopy area will require sampling at the cluster level, as was recently reported for eastern redcedar (Juniperus virginiana L.; Starks et al. 2011).

Table 3. Tests using two pooled populations of redberry juniper to predict aboveground mass (AGM) of the third population, and trees from site 1 to predict AGM of trees from site 3 , based on canopy area/AGM regressions.

\begin{tabular}{|c|c|c|c|c|c|c|}
\hline \multirow[b]{2}{*}{ Test $^{1}$} & \multicolumn{3}{|c|}{ Variable intercept } & \multicolumn{3}{|c|}{ Intercept at zero } \\
\hline & Equation & $r^{2}$ & $\begin{array}{l}\% \text { Deviation } \\
(\text { mean } \pm \text { SE) }\end{array}$ & Equation & $r^{2}$ & $\begin{array}{l}\% \text { Deviation } \\
(\text { mean } \pm \mathrm{SE})\end{array}$ \\
\hline 1 and 2 for 3 & $Y=8.30 x-6.47$ & 0.89 & $-4.04 \pm 3.63$ & $Y=8.00 x$ & 0.89 & $-2.13 \pm 0.07$ \\
\hline 1 and 3 for 2 & $Y=8.57 x-3.92$ & 0.95 & $9.43 \pm 7.69$ & $Y=8.49 x$ & 0.95 & $1.11 \pm 0.24$ \\
\hline 2 and 3 for 1 & $Y=8.46 x-1.03$ & 0.86 & $24.68 \pm 7.47$ & $Y=8.44 x$ & 0.86 & $2.41 \pm 0.60$ \\
\hline 1 for 3 & $Y=8.98 x-11.29$ & 0.84 & $2.96 \pm 3.91$ & $Y=8.01 x$ & 0.83 & $-8.71 \pm 0.11$ \\
\hline
\end{tabular}

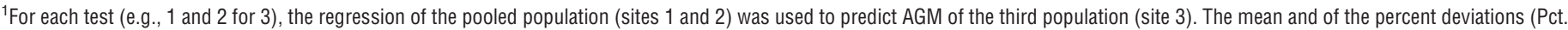
Dev.) between predicted and actual AGM of the third population are shown for regressions with a variable $Y$ intercept and with the $Y$ intercept as zero. $Y=$ AGM; $X=$ canopy area. Sample $n$ for sites 1 and $2=27$; for sites 1 and $3=30$; for sites 2 and $3=23$; for site $1=17$. 

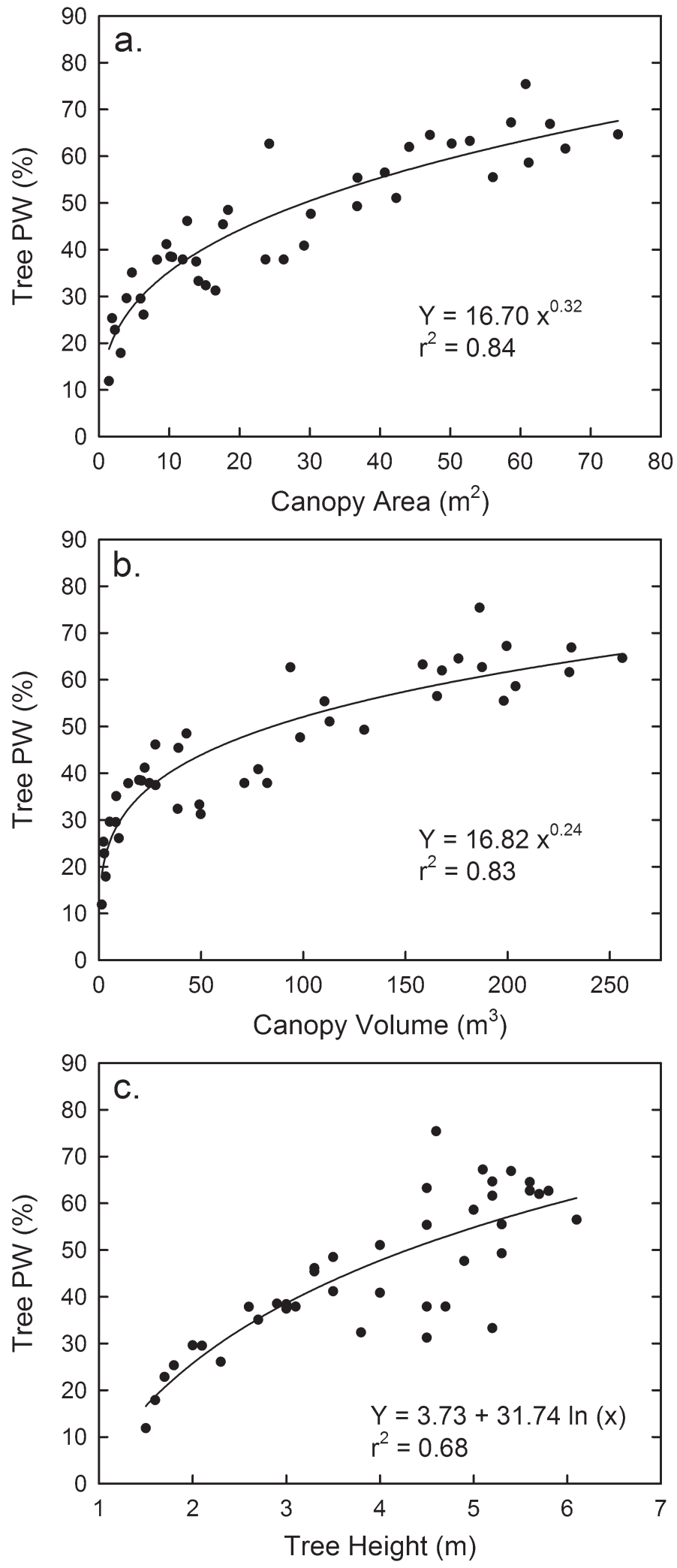

Figure 4. Relationship between a, canopy area and percentage of aboveground biomass that is wood (PW), b, canopy volume and PW, and $\mathbf{c}$, tree height and PW of individual redberry juniper plants in north Texas.

\section{ACKNOWLEDGMENTS}

Copper Breaks State Park, the Whatley Ranch and the Y Ranch provided harvest sites for this project. Andy Bell, David Jones, Gerral Schulz, and Steve Dowhower assisted with data collection.

\section{LITERATURE CITED}

Alvarez, J. A., P. E. Villagra, R. Villalba, M. A. Cony, and M. Alberto. 2011. Wood productivity of Prosopis flexuosa D.C. woodlands in the central Monte: influence of population structure and tree-growth habit. Journal of Arid Environments 75:7-13.

Ansley, R. J., M. Mirik, and M. J. Castellano. 2010. Structural biomass partitioning in regrowth and undisturbed mesquite (Prosopis glandulosa): implications for bioenergy uses. Global Change Biology Bioenergy 2:26-36.

Ansley, R. J., W. E. Pinchak, and D. N. Ueckert. 1995. Changes in redberry juniper distribution in northwest Texas (1948 to 1982). Rangelands 17:49-53.

Ansley, R. J., B. A. Trevino, and P. W. Jacoby. 1998. Intraspecific competition in honey mesquite: leaf and whole plant responses. Journal of Range Management 51:345-352

Ansley, R. J., H. T. Wiedemann, M. J. Castellano, and J. E. Slosser. 2006. Herbaceous restoration of juniper-dominated grasslands with chaining and fire. Rangeland Ecology \& Management 59:171-178.

Asner, G. P., S. R. Archer, R. F. Hughes, R. J. Ansley, and C. A. Wessman. 2003. Net changes in regional woody vegetation cover and carbon storage in Texas drylands, 1937-1999. Global Change Biology 9:316-335.

Booth, D. T., S. E. Cox, and R. D. Berryman. 2006. Precision measurements from very large scale aerial digital imagery. Environmental Monitoring and Assessment 112:293-307.

Brand, G. J., And W. B. SMith. 1985. Evaluating allometric shrub biomass equations fit to generated data. Canadian Journal of Botany 63:64-67.

Bryant, F. C., And M. M. Kothmann. 1979. Variability in predicting edible browse from crown volume. Journal of Range Management 32:144-146.

Cleary, M. B., E. Pendall, and B. E. Ewers. 2008. Testing sagebrush allometric relationships across three fire chronosequences in Wyoming, USA. Journal of Arid Environments 72:285-301.

Davies, K. W., S. L. Petersen, D. D. Johnson, D. B. Davis, M. D. Madsen, D. L. Zvirzoin, AND J. D. BATES. 2010. Estimating juniper cover from National Agriculture Imagery Program (NAIP) imagery and evaluating relationships between potential cover and environmental variables. Rangeland Ecology \& Management 63:630-637.

Dye, K. L., D. N. Ueckert, and S. G. Whisenant. 1995. Redberry juniper-herbaceous understory interactions. Journal of Range Management 48:100-107.

El Fadl, M. A., S. Gronski, H. Asah, A. Tipton, T. E. Fulbright, and P. Felker. 1989. Regression equations to predict fresh weight and three grades of lumber from large mesquite (Prosopis glandulosa var. glandulosa) in Texas. Forest Ecology and Management 26:275-284.

Felker, P., G. H. Cannell, P. R. Clark, J. F. Osborn, and P. Nash. 1983. Biomass production of Prosopis species (mesquite), Leucaena, and other leguminous trees grown under heat/drought stress. Forest Science 29:592-606.

Grier, C. C., K. J. Elliot, and D. G. McCullough. 1992. Biomass distribution and productivity of Pinus edulis-Juniperus monosperma woodlands of northcentral Arizona. Forest Ecology and Management 50:331-350.

Hicks, R. A., AND W. A. Dugas. 1998. Estimating Ashe juniper leaf area from tree and stem characteristics. Journal of Range Management 51:633-637.

Huang, C., G. P. Asner, R. E. Martin, N. N. Barger, and J. C. Neff. 2009. Multiscale analysis of tree cover and aboveground carbon stocks in pinyon-juniper woodlands. Ecological Applications 19:668-681.

Hughes, H. G., L. W. Varner, AND L. H. BlankenSHIP. 1987. Estimating shrub production from plant dimensions. Journal of Range Management 40:367-369.

Hughes, R. F., S. R. Archer, G. P. Asner, C. A. Wessman, C. McMurtry, J. Nelson, and R. J. ANSLEY. 2006. Changes in aboveground primary production and carbon and nitrogen pools accompanying woody encroachment in a temperate savanna. Global Change Biology 12:1733-1747. 
Jenkins, J. C., D. C. Chojnacky, L. S. Heath, and R. A. Birdsey. 2003. National-scale biomass estimators for United States tree species. Forest Science 49:12-35.

LudWig, J. A., J. F. Reynolds, And P. D. Whitson. 1975. Size-biomass relationships of several Chihuahuan desert shrubs. The American Midland Naturalist 94:451-461.

Masera, O., A. Ghilardi, R. Drigo, and M. A. Trossero. 2006. WisdoM: a GIS-based supply demand mapping tool for woodfuel management. Biomass and Bioenergy 30:618-637.

Mason, L. R., AND S. S. Hutchings. 1967. Estimating foliage yields on Utah juniper from measurements of crown diameter. Journal of Range Management 20:161-166.

Massada, A. B., Y. Carmel, G. E. Tzur, J. M. Grünzweig, and D. YakiR. 2006. Assessment of temporal changes in aboveground forest tree biomass using aerial photographs and allometric equations. Canadian Journal of Forestry Research 36:2585-2594.

McGinnis, T. W., C. D. Shook, And J. E. Keeley. 2010. Estimating aboveground biomass for broadleaf woody plants and young conifers in Sierra Nevada, California, forests. Western Journal of Applied Forestry 25:203-209.

McPherson, G. R., And H. A. Wright. 1990. Effects of cattle grazing and Juniperus pinchotii canopy cover on herb cover and production in western Texas. The American Midland Naturalist 123:144-151.

Miller, E. L., R. O. Meeuwig, AND J. D. Budy. 1981. Biomass of singleleaf pinyon and Utah juniper. Ogden, UT, USA: US Department of Agriculture Intermountain Forest and Range Experiment Station. Research Paper INT-273. 20 p.

Miller, R. F., L. E. Eddleman, and R. F. Angell. 1987. Relationship of western juniper stem conducting tissue and basal circumference to leaf area and biomass. Great Basin Naturalist 47:349-354.

Navar, J., E. Mendez, A. Najera, J. Graciano, V. Dale, and B. Parresol. 2004. Biomass equations for shrub species of Tamaulipan thornscrub of north-eastern Mexico. Journal of Arid Environments 59:657-674.

[NOAA] National Oceanic and Atmospheric Administration. 2006. National Climatic Data Center. Available at: http://www.ncdc.noaa.gov/oa/ncdc.html. Accessed April 2006

Northup, B. K., S. F. Zitzer, S. Archer, C. R. McMurtry, and T. W. Boutton. 2005. Above-ground biomass and carbon and nitrogen content of woody species in a subtropical thornscrub parkland. Journal of Arid Environments 62:23-43.

[NRCS] US Department of Agriculture, Natural Resources Conservation Service. 2009. Plants database. Available at: http://plants.usda.gov. Accessed January 2009.

NRCS. 2011. Soil series descriptions. Available at: http://soils.usda.gov. Accessed August 2011.
Owens, M. K., And M. C. Schreiber. 1992. Seasonal gas exchange characteristics of two evergreen trees in a semiarid environment. Photosynthetica 26:389-398.

Padron, E., and R. M. Navarro. 2004. Estimation of above-ground biomass in naturally occurring populations of Prosopis pallida (H.\& B. ex. Willd.) H.B.K. in the north of Peru. Journal of Arid Environments 56:283-292.

PeEK, J. M. 1970. Relation of canopy area and volume to production of three woody species. Ecology 51:1098-1101.

Rosenschein, A., T. Tietema, and D. 0. Hall. 1999. Biomass measurement and monitoring of trees and shrubs in a semi-arid region of central Kenya. Journal of Arid Environments 42:97-116.

SABIN, B. S. 2008. Relationship between allometric variables and biomass in western juniper (Juniperus occidentalis) [thesis]. Corvallis, OR, USA: Oregon State University. 129 p.

[SCS] Soll Conservation Service. 1988. Texas brush inventory. Temple, TX, USA: United States Department of Agriculture, Soil Conservation Service. Misc. Report. 89 p.

Starks, P. J., B. C. Venuto, J. A. Eckroat, and T. Lucas. 2011. Measuring eastern redcedar (Juniperus virginiana L.) mass with the use of satellite imagery. Rangeland Ecology \& Management 64:178-186.

Strand, E. K., L. A. Vierling, A. M. S. Smith, and S. C. Bunting. 2008. Net changes in aboveground woody carbon stock in western juniper woodlands, 1946-1998. Journal of Geophysical Research 113:G01013. doi:10.1029/2007JG000544

Thomson, E. F., S. N. Mirza, And J. Afzal. 1998. Predicting the components of aerial biomass of fourwing saltbush from shrub height and volume. Journal of Range Management 51:323-325.

Tiedemann, A. R., and J. 0. KLemmedson. 2000. Biomass and nutrient distribution and system nutrient budget for western juniper in central Oregon. Northwest Science 74:12-24.

Tietema, T. 1993. Biomass determination of fuelwood trees and bushes of Botswana, Southern Africa. Forest Ecology and Management 60:257-269.

Ueckert, D. N., R. A. Phillips, J. L. Petersen, X. B. Wu, and D. F. Waldron. 2001. Redberry juniper canopy cover dynamics on western Texas rangelands. Journal of Range Management 54:603-610.

Whisenant, S. G., and D. F. Burzlaff. 1978. Predicting green weight of mesquite (Prosopis glandulosa Torr.). Journal of Range Management 31:396-397.

Williams, R. J., A. Zerihun, K. D. Montagu, M. Hoffman, L. B. Hutley, and X. Chen. 2005. Allometry for estimating aboveground tree biomass in tropical and subtropical eucalypt woodlands: towards general predictive equations. Australian Journal of Botany 53:607-619. 